\title{
Science, Technology and Preservation of the Life-world
}

\author{
DERMOT MORAN \\ School of Philosophy, University College Dublin 4, Ireland. \\ E-mail: Dermot.moran@ucd.ie
}

\begin{abstract}
The opposition between rationality and irrationality is often portrayed as a struggle between rational evidence-based science and irrational, ungrounded myth. I shall argue that this is too simplistic and that different forms of rationality need to be recognised - in particular, the rationality of everyday life. All scientific inquiry and reasoning is based and depends upon the practices, activities and antecedent beliefs of human knowers, who are embedded in cultural life-worlds in ways that science has hitherto ignored. Progress in civilisational rationality requires that the rationality of the life-world be understood.
\end{abstract}

One of the aims of this dialogue is to address the apparent growth and spread of irrationality. Our complex world is increasingly dependent on advanced technologies that are themselves dependent on theoretical scientific inquiry and discovery. Yet at the same time there seems to be a parallel growth in extra-scientific, non-scientific or indeed antiscientific worldviews. There is a widespread fear that this growing irrationalism threatens the very institution of science.

In response, many countries have taken the step of developing policies for advancing the public understanding of science and advocate increasing time spent on science in schools. Some compare unfavourably the amount of time spent on teaching science in primary schools with the amount of time spent on teaching religion. ${ }^{1}$ It is one of the aims of this dialogue to explore the evidence base that might underpin reasons for these 'alternative' views that challenge the ideals of the European Enlightenment.

My contention is that the sciences themselves must pay more attention to human social practices and beliefs that, I maintain, do not so much threaten science as actually underpin and make scientific inquiry possible. One of the greatest dangers to scientific advance is the unquestioned assumption that only science possesses rationality or that its rationality and value system is so comprehensive as to be able to replace the rationality and values of social life.

The everyday world has its own patterns of rationality that must also be understood and appreciated if scientific understanding is to be promoted. The scientist is a human 
being, and even at his or her most detached, is still a responsible member of the human community and responsive to its values. The relationship between scientific method and everyday life is very complex and needs to be considered with more care; indeed it will sharpen our understanding of science just as much as it will give us new scientific knowledge of everyday cultural life. The very concept of a 'worldview' and how it maintains a grip on our thinking is something that has preoccupied philosophers, sociologists, anthropologists and theologians, but it is rarely considered to merit scientific study. In this short paper, I will examine critically some of these issues concerning this tension between scientific method and worldview from the point of view of philosophy.

The modern scientific worldview itself emerged in Europe from the seventeenth century onward - at least in part - in reaction to religious world views. Galileo's struggle with the Papacy and the Inquisition is often cited as an example of the natural enmity between science and religion, and between reason and superstition/blind prejudice.

The ongoing battle between evolutionary theories and creationist theories (including 'intelligent design') is regarded as the contemporary equivalent of Galileo's struggle. And Creationism is not just an American phenomenon. For instance, in the UK, the National Trust's newly opened visitor centre for the Giant's Causeway in Northern Ireland explains the spectacular formation as the result of volcanic eruption 60 million years ago.

But in the multimedia presentation, there is a reference to the 'Young Earth', and the audio continues: 'Young Earth Creationists believe that the Earth was created some 6000 years ago. This is based on a specific interpretation of the Bible and in particular the account of creation in the book of Genesis... Young Earth Creationists continue to debate questions about the age of the Earth.'

The inclusion of reference to creationism in this context - where it is presented as a credible alternate view - has been criticised. ${ }^{2}$ This reference was inserted presumably as a sop to Christian fundamentalist belief, which has a strong presence in Northern Ireland. The scientist and advocate of atheism, Richard Dawkins, commented that the Trust should not have given in to pressure from 'intellectual baboons' and that it was regrettable that the Trust had 'paid lip-service to the ignorant bigotry' of fundamentalists. ${ }^{3}$

In October 2012, after a review, the National Trust amended its audio presentation to endorse the scientific view, stating that there is 'clear understanding among scientists that the heat of the earth was the driving force behind the formation of the Giant's Causeway'. ${ }^{4}$ In fact, as is often pointed out, the mainstream Christian sects do not oppose evolutionary scientific explanations nor do they believe the Earth is only a few thousand years old. Nevertheless, religious faith is often cited as a major force opposing scientific progress.

It is not just traditional religious worldviews, however, that are seen to stand in opposition to the scientific outlook; there is a myriad of various health and lifestyle practices that appeal to concepts and principles that are antithetical to science. Witness the popularity of horoscopes, TV psychics, palm readings, Tarot cards, alternative and complementary medicine, psychic healing, and so on.

It is pointed out that science deliberately ignores other explanatory accounts, e.g. the proposed justification of acupuncture to be found in traditional Chinese medicine. Of course, it is possible to absorb a set of techniques (yoga is a prime example) into science, under the strict proviso that the justification for these techniques must ultimately be 
provided in terms of evidence-based scientific verification. In other words, any scientific explanation justifying acupuncture will not make reference to 'chi' energy-flows in the body but will explain any efficacy in terms of scientific physiology.

But can one really divorce such practices from the overall worldview from which they come? Clearly, the Catholic Cardinal Joseph Ratzinger, recently Pope Benedict, did not think yoga could be completely divorced from its Eastern worldview whose monism and impersonal approach he took to be incompatible with Christianity. Thus, in a letter addressed to his bishops, entitled Letter to the Bishops of the Catholic Church on Some Aspects of Christian Meditation, he claimed that 'physical exercises automatically produce a feeling of quiet and relaxation, pleasing sensations, perhaps even phenomena of light and of warmth, which resemble spiritual well-being. To take such feelings for the authentic consolations of the Holy Spirit would be a totally erroneous way of conceiving the spiritual life'.

Whether Ratzinger was right or wrong about the spiritual aspects of yogic exercise, he was surely right to point out that it is difficult to extract a single practice or belief from the whole edifice of a worldview. Worldviews are by their nature, overarching and holistic. Indeed, philosophers of science such as Thomas Kuhn believed, in an analogous manner, that concepts found in one scientific theory could not be simply imported wholesale into a completely different theory that belonged to a different paradigm. ${ }^{6}$ Thus, he maintained, 'atoms' simply do not mean the same thing in ancient Greek cosmology and in contemporary physics.

There are current proponents of the scientific world view - Richard Dawkins is a prime example - who believe that all religious, mystical and 'magical' ways of thinking must be opposed and rejected. Thus, in 2008, Dawkins warned parents about exposing their children to the Harry Potter books on the basis that these books purveyed an 'anti-scientific' worldview that included magical powers, spells and wizards. Dawkins believes the scientific world view - based on evidence - is directly opposed to the 'mythical' outlook. However, to contrast starkly between scientific evidence and mythical 'non-sense' is rather narrow and misleading, and misunderstands the complex web of belief within which human beings function.

Just to put my views in context (especially for an audience consisting primarily of scientists) as an academic philosopher, my area of specialisation is phenomenology - the description of the world as it is experienced from the subjective or first-person point of view. It is often observed that the modern natural sciences adopt an objective or 'third-person' stance, whereas our own experience is always through a first-person, subjective perspective.

Phenomenology aims to describe the nature of first-person experience but to do so in a manner that generates scientific truth. And since our first-person experiences affect all our other activities - from making decisions in a courtroom as a member of a jury, to reviewing scientific applications for grant funding, or deciding whether a scientific article merits publication in a peer-reviewed journal, the understanding of how our first-person experiences are constituted ought to be a matter of serious concern for the other sciences as well.

Indeed, traditionally, phenomenology claimed to be a kind of bedrock science, a science of sciences, since it balanced the more or less artificial objectivist approach of the exact sciences with an understanding of the functioning of subjectivity. Objectivity is always a hard-won achievement of human cooperation. 
Phenomenology in this sense historically has close ties with empirical psychology. The teacher of the acknowledged founder of phenomenology Edmund Husserl (1859-1938) was the early psychologist Franz Brentano (1838-1917). Husserl himself trained as a mathematician. He was a student of Weierstrass, friend and colleague of the mathematicians Georg Cantor (1845-1918) and David Hilbert (1862-1943). The theoretical physicist Hermann Weyl (1885-1955) was one of Husserl's students at Göttingen. I mention these facts to show that Husserl was in no way anti-scientific; indeed, his chief concern was to remove intellectual impediments to genuine science.

In fact, phenomenology claimed to be a science that was based entirely on evidence with no element of theory-construction or metaphysical speculation. Phenomenology aims to comprehend the uniquely human way of understanding the world as way of rescuing the sciences from a brutalist anti-humanism that the public has been quick to recognise in a crude rhetoric that may be described as 'scientism' - the view that there is only science.

Phenomenology is particularly interested in the manner in which humans dwell in a world. We live as human beings in a distinctly and peculiarly human environment and science belongs in this environment also. Human beings are embodied and embedded in social, historical, linguistic and cultural milieux. In much the same way as spiders generate webs, human beings develop and constitute their social worlds out of their own practices. The French phenomenologist Maurice Merleau-Ponty (1908-1961) captures this first-person sense of absorption in the world well when he writes in his Phenomenology of Perception: ${ }^{7}$

Our own body is in the world as the heart is in the organism; it keeps the visible spectacle constantly alive, it breathes life into it and sustains it inwardly, and with it forms a system.

As embodied, social and historical beings we are always creatures of our time. Our views are formed not just by our scientific education but by all the social and cultural forces that surround us.

My own particular areas of study includes trying to understand the background of the inter-subjective, shared 'life-world' (Lebenswelt), which forms a backdrop to all experience. This notion of the life-world was introduced into phenomenology by Edmund Husserl who himself was attempting to rethink a phenomenon first described by the Austrian physicist and philosopher Ernst Mach (1838-1916) and the positivist philosopher Richard Avenarius (1843-1896); namely, how we have a sense of a pre-given natural world that is simply there before us and whose apparent lawfulness it is the function of science to explain. All the sciences presume the existence of this world, but the manner in which human beings experience the world's spatiality, temporality, causation, and so on, is not the same as the manner in which these phenomena are expressed by the sciences.

We are all familiar with the fact that 'lived time' is quite different in its fluctuations from 'clock time'. GPS systems are very different from our own intuitive sense of where we live and how far we are from home.

The sciences have only recently become interested in these specifically human, everyday ways of experiencing the world. For a long time this domain was left to anthropologists interested in the worldviews of pre-technological peoples. But there is a specific science of the everyday lived-world, a science of the life-world, in short. 
Part of the supposed continuance of so-called magical or mythical ways of thinking actually is more properly understood as the resistance of the life-world. We have to recognise that part of the success of the modern sciences was based on the deliberate methodological exclusion of the purely subjective qualitative aspects of experience (Galileo's distinction between real and primary properties and human subjective-relative properties in a paradigm case). Galileo wrote in The Assayer: ${ }^{8}$

... I think that tastes, odors, colors, and so on are no more than mere names so far as the object in which we place them is concerned, and that they reside only in the consciousness. Hence, if the living creature were removed, all these qualities would be wiped away and annihilated. ... To excite in us tastes, odors, and sounds I believe that nothing is required in external bodies except shapes, numbers, and slow or rapid movements. I think that if ears, tongues, and noses were removed, shapes and numbers and motions would remain, but not odors or tastes or sounds.

The problem is that we cannot go on excluding the human viewpoint and still expect to have comprehensive science. One of the great discoveries of twentieth century science was that any focus on the individual organism needed to be complemented by a study of the ecosystem, and indeed that life has to be understood within the context of what has become known as the biosphere. Similarly, the sciences have to pay attention to human ways of existing.

There has been a kind of fetishisation of the natural, and especially the mathematically exact, physical sciences. Just as the exactness of classical geometry appealed to scientists (such as René Descartes and Galileo) as the model of scientific method in the early modern period so theoretical physics became the model science for the nineteenth and twentieth centuries.

For many, including the Logical Positivists of the Vienna Circle, physics was considered to be the model of what all reasoning should be and there were many efforts to reduce other sciences to physics. This reductionism is actually extremely limiting and distorting on scientific development.

Indeed, advances in the cognitive sciences, for instance, have shown more and more the need for an enriched and more nuanced understanding of human consciousness and human behaviour generally (and here we need to overcome the legacy of almost a century of behaviourism in psychology). We also have to become accommodated to the idea that the very concept of science means systematic knowledge, and it has to be understood as much broader than the natural sciences that have too often been taken as the paradigmatic sciences. Science has to be understood in a way that includes the human sciences, or humanities. Human sciences include such disciplines as politics, economics, history, sociology, law, psychology and philosophy.

There is some dispute as to whether these humanistic sciences are currently operating at some pre-scientific level, and will do until such time as they establish their own objective, quantitative methodologies. But despite many attempts in the twentieth century, it has become clear that there are important and indeed crucial aspects of these disciplines that cannot be subsumed under purely quantitative approaches. This is not an anti-scientific position; rather, it recognises the need for pluralism in our understanding of different sciences and the methods appropriate to study diverse phenomena. One must 
have a pluralist conception of science - and to assert this pluralism is, I insist, not to promote relativism.

Indeed, the real challenge is to recognise that beliefs and practices function inside of larger more holistic frameworks - worldviews or forms of life, broadly speaking - and at the same time to be able to allow for dialogue and critique across worldviews. One must not concede that worldviews are incommensurate or that all are equally valid (the relativist claim).

For rationality to prevail in our social practices, we need a way of dialoguing and bridging between systems of belief. There is indeed need for criticism, but we also need to recognise why human beings remain deeply entrenched in their cultural traditions.

Another stumbling block to the advance of scientific rationalism is the confusion unfortunately too often found even at the level of national and international bodies promoting scientific policy - that identifies scientific thinking with technological advance and especially with economic prosperity.

In the contemporary world, technological advance has been confused with scientific advance. In this regard, the German philosopher Martin Heidegger, a most creative critic of Husserlian phenomenology, speaks in general of a kind of 'technicity' (die Technik) as an outlook that dominates and frames the contemporary worldview.

We live in the era of what is often called 'technoscience', a term coined by the French philosopher Gaston Bachelard (1884-1962). Contemporary science cannot be done without technology and without direct or indirect support from political and social institutions, both national and international, as is evident, for instance, in the case of the Large Hadron Collider in Switzerland. Heidegger has pointed out that technology is misunderstood if it is construed merely as a means to do science. Rather, for Heidegger, as he puts it in his famous essay 'The question concerning technology', technology is a very specific way of revealing the world in terms of calculation and the ordering of information.

It is said that modern technology is something incomparably different from all earlier technologies because it is based on modern physics as an exact science. Meanwhile we have come to understand more clearly that the reverse holds true as well: Modern physics, as experimental, is dependent upon technical apparatus and upon progress in the building of apparatus. The establishing of this mutual relationship between technology and physics is correct. ${ }^{9}$

What concerns Heidegger is that technological enframing is often seen as the sole way of revealing human existence to itself (art, for him, is another form of revealing).

We need to think much more carefully about this complex interdependency between science and technology. Technology is not just applied science. It has its own inbuilt kind of rationale that may not be identical with the kind of rationality aspired to by the pure theoretical physicist, for example, and certainly it may differ from the rationality involved in ordering a good society.

Technology, moreover, is not the enemy of religious worldview. We have the strange spectacle of fundamentalist religious groups such as the Taliban employing the latest missile guidance technology, satellite phones, email and so on, yet destroying schools that provide the very basis of education needed to pursue knowledge. Understanding the difference between science and technology is one way of ensuring that the proper character of science is preserved. 
Part of the problem is that many scientists themselves are in the grip of a particularly narrow outlook about what is science itself. There is an idealised version of pure science that is regularly encountered in the classroom and in academia, but there is also the difficult situation that science is in thrall not just to the latest technology but also, in capitalist societies to certain funding requirements (e.g. major drug companies, military investment, and so on). One particular refrain that is quite misleading is that science is value-free. The developmental biologist Lewis Wolpert, one of our partners in this dialogue, has written in his essay 'Is science dangerous?'

... reliable scientific knowledge is value-free and has no moral or ethical value. Science tells us how the world is. That we are not at the centre of the universe is neither good nor bad, nor is the possibility that genes can influence our intelligence or our behaviour. Dangers and ethical issues only arise when science is applied as technology. However ethical issues can arise in actually doing the scientific research, such as doing experiments on humans or animals, as well as issues related to safety. The problem is the conflation of science and technology. ${ }^{10}$

While I agree with Professor Wolpert that the conflation of science and technology generates a certain confusion and misunderstanding of the nature of both, I disagree with him when he claims that science is value-free - something I believe to be a dangerous mind-set.

At the very same time, those promoting science often present it as having a unique set of values by which we should live in the modern secular age. Science cannot both be value-free and offer the values by which we should live our lives. So we need to reflect a little on the relation between science and value. In relation to making pronouncements that have an impact in the community, scientists often go well beyond their brief in their comments. Recent examples include Stephen Hawking's claim in his The Grand Design that philosophy is dead, or redundant, since it has not kept up with scientific advances. ${ }^{11}$

Now, without becoming too theoretical in the direction of epistemology, the science of knowledge, it is important to point out that 'truth' is a value. The pursuit of truth is a value that requires many other values - such as intellectual honesty, fairness, openmindedness, impartiality, recognition of one's own fallibility, tenacity, humility, and so on. Moreover, as we have pointed out, scientific inquiry does not take place in a vacuum. It takes place primarily in institutions that are highly regulated and driven by values (such as the desire for profit) that may be alien to the scientific process proper. In addition, there is a panoply of laws, directives, conventions regarding reporting, codes of practice, professional codes, ethics boards, and so on that oversee the conduct of scientific research and promote a system of values such as dignity and respect, academic freedom, and so on. Science is an institutional process and it is also a complex social process.

Let me briefly consider an aspect of the human face of science that shows that the issue of the rationality cannot be divorced from human practices. The scientific process advances largely on the basis of peer reviewing. The test for evaluating the truth-claims of a scientific paper is to have that paper rigorously evaluated by peers in a double blind refereeing system, which is now the norm for scientific publication. But the peer review system is not without serious flaws. It is - as Churchill said of democracy - the 
least-worst system. As Tracey Brown, director of the Sense About Science organisation and another participant in this dialogue, has put it in her informative study, peer review exhibits all the strengths and the weaknesses of a system of organised human judgement.

The peer reviewing system - and even the concept of authorship - is interpreted and applied differently in the various scientific disciplines. Of course, one must distinguish between pre-publication reviewing and then the business of reconfirmation of results that takes place after an article has been published. The pre-publication system has been compared with other forms of systematic and organised human judgement as in a jury's deliberations. Undoubtedly mistakes can be made, and prejudices (especially ones in favour of confirming antecedently held positions) definitely are brought to bear.

There have been some significant recent documented failures of the system. Perhaps one of the most notorious is the case of the Korean scientist Wu-Suk Hwang, who claimed to have cloned a human embryo and extracted stem cells from it.

Hwang, a biologist from Seoul National University published his results in Science. ${ }^{12,13}$ It soon came to light - initially as a result of questions asked about the source of the human eggs (he claimed that laboratory assistants had donated them), that these results were fabricated, leading to a huge scandal. On 12 January 2006, Science retracted the two papers. Is this incident to be regarded as a triumph of science or a disaster? The original peer-review process did not find the fraud.

Although sceptical questions - and ethical issues - were raised, the fraud was subsequently discovered through a whistle-blower from Hwang's laboratory. ${ }^{14}$ The incident certainly highlighted many unsavoury aspects of the rush to announce important breakthrough results. It showed how the pressure of gaining grants led to muting of criticism. National pride was at stake. All these issues enter into science. Science is a practice of human beings. We cannot subtract this inevitably subjective and intersubjective dimension - there are power structures at work in science.

If scientific rationality is to be promoted, then scientific practices must themselves be carefully scrutinised. Science does not dwell apart in a vacuum but belongs in the human world. The simple contrast between scientific method and extra-scientific prejudice cannot stand. What is needed is a more nuanced recognition that science too must struggle to purge itself of its own irrationalities and that other domains of life often promote and preserve the very values that sciences claims to espouse.

\section{References and Notes}

1. See, for example, the recent report for Ireland of the Economic and Social Research Institute, which found that religion was given twice the amount of time in the Irish primary school curriculum. S. McCoy, E. Smyth and J. Banks (2012) Learning in Focus. The Primary Classroom: Insights from the Growing Up in Ireland Study (Dublin: Economic and Social Research Institute). Available at http://www.esri.ie/ UserFiles/publications/BKMNEXT205.pdf

2. See the Museum Associations journal report of July 2012 at http://www. museumsassociation.org/museums-journal/news/11072012-controversy-overcreationism-at-giants-causeway 
3. See the report in the Belfast Telegraph for 7 July 2012 to be found at http:// www.belfasttelegraph.co.uk/news/local-national/northern-ireland/richard-dawkinscreationism-at-giants-causeway-is-intellectual-baboonism-16181959.html

4. See the report 'Trust Amends Causeway Centre "Creationist" Exhibit,' BBC News Northern Ireland, 3 October 2012, at http://www.bbc.co.uk/news/uk-northernireland-19814284

5. See the letter signed by the then Cardinal Joseph Ratzinger and issued in 1989 by the Congregation for the Doctrine of the Faith to the Bishops of the Catholic Church, On Some Aspects of Christian Meditation. The text can be found at http://www.ewtn. com/library/curia/cdfmed.htm

6. T. S. Kuhn (1962) The Structure of Scientific Revolutions, 1st edn (Chicago, IL: University of Chicago Press).

7. M. Merleau-Ponty (1962) The Phenomenology of Perception. Translated by C. Smith (London \& New York: Routledge \& Kegan Paul).

8. Galileo (1623) The Assayer. Translated by S. Drake. In: S. Drake (Ed.) Discoveries and Opinions of Galileo (New York: Doubleday, 1957), pp. 274-277.

9. M. Heidegger (1993) The question concerning technology. In: D. Farrell Krell (Ed.) Martin Heidegger Basic Writings (New York: HarperCollins), pp. 319-320.

10. L. Wolpert (2005) The Medawar Lecture 1998: is science dangerous? Philosophical Transactions of the Royal Society of London B. Biological Sciences, 360(1458), pp. $1253-1258$.

11. S. Hawking and L. Mlodinow (2010) The Grand Design: New Answers to the Ultimate Questions of Life (London: Bantam Press).

12. W.-S. Hwang, Y. J. Ryu, J. H. Park, E. S. Park, E. G. Lee, J. M. Koo, H. Y. Jeon, B. C. Lee, S. K. Kang, S. J. Kim, C. Ahn, J. H. Hwang, K. Y. Park, J. B. Cibelli and S. Y. Moon (2004) Evidence of a pluripotent human embryonic stem cell line derived from a cloned blastocyst. Science, 303, pp. 1669-1674.

13. W.-S. Hwang, S. I. Roh, B. C. Lee, S. K. Kang, D. K. Kwon, S. Kim, S. J. Kim, S. W. Park, H. S. Kwon, C. K. Lee, J. B. Lee, J. M. Kim, C. Ahn, S. H. Paek, S. S. Chang, J. J. Koo, H. S. Yoon, J. H. Hwang, Y. Y. Hwang, Y. S. Park, S. K. Oh, H. S. Kim, J. H. Park, S. Y. Moon and G. Schatten (2005) Patient-specific embryonic stem cells derived from human SCNT blastocysts. Science, 308, 1777-1783.

14. See the special report published in Nature on 11 January 2006, available at http:// www.nature.com/news/2006/060109/full/news060109-8.html. On 26 October 2009 Nature reported that Hwang had been convicted of embezzlement and bioethical violations (but not fraud) and sentenced to two years in jail (see http://www.nature. com/news/2009/091026/full/4611181a.html).

\section{About the Author}

Dermot Moran is Professor of Philosophy at University College Dublin and is a Member of the Royal Irish Academy. He is a graduate of University College Dublin and Yale University. He has published widely on medieval philosophy and contemporary European philosophy (especially phenomenology). 